\title{
Effect of Anastomosis Technique on Pancreatic Fistula Formation in Proximal Pancreaticoduodenectomy
}

\author{
Ozgur Yildirim Yildirim ${ }^{1}$ and Nazmi Özer ${ }^{2}$ \\ ${ }^{1}$ Izmir Katip Celebi Universitesi, Izmir, Turkey \\ ${ }^{2}$ Adana City Research and Training Hospital, Adana, Turkey
}

\begin{abstract}
Objective: To find out the association between the pancreatic fistula development and the pancreaticoduodenectomy anastomosis technique performed in three different ways; namely, telescopic pancreatojejunostomy (PJ), ducto-mucosal Wirsungo jejunostomy (WJ), and Peng's variant of the telescopic technique.

Study Design: A descriptive study.

Place and Duration of Study: Izmir Katip Celebi Universitesi Hospital, Turkey, from January 2011 to January 2018.

Methodology: A total of 144 proximal pancreaticoduodenectomy procedures were performed at the study centre. Patients' data was obtained from the outpatient files and hospital information system, retrospectively; and divided into three groups according to the pancreatic anastomosis techniques. All three groups were compared in terms of eight parameters. Preoperative parameters were age, gender, and serum direct bilirubin values; whereas, postoperative parameters were pathology, pancreatic fistula, drain amylase, serum albumin value and early mortality.

Results: All variables by anastomosis type belonging to three groups differed for fistula rates $(p=0.384)$, pathology types $(p=0.142)$, preoperative bilirubin $(p=0.631)$ and postoperative albumin $(p=0.516)$ levels, early mortality $(p=0.242)$ parameters without reaching statistical significance $(p>0.05)$; however, the low anastomosis leak rates in Peng's technique were remarkable. POPF (post-operative pancreatic fistula) developed in 34\% patients under 60 years vs. $17.6 \%$ patients over 60 years of age $(p=0.029)$; and $13.7 \%$ females vs. $29.9 \%$ of male patients $(p=0.032)$.

Conclusion: No factors other than age and gender were found to be significant alone in the development of pancreatic fistula after proximal pancreaticoduodenectomy.
\end{abstract}

Key Words: Postoperative pancreatic fistula, Pancreaticoduodenectomy, Pancreatojejunostomy, Telescopic pancreatojejunostomy (PJ), Ducto-mucosal Wirsungo jejunostomy (WJ), Peng's telescopic technique.

How to cite this article: Yildirim OY, Özer N. Effect of Anastomosis Technique on Pancreatic Fistula Formation in Proximal Pancreaticoduodenectomy. J Coll Physicians Surg Pak 2020; 30(05):480-484. DOI: https://doi.org/10.29271/jcpsp.2020.05.480.

\section{INTRODUCTION}

Proximal pancreaticoduodenectomy (PPD, Whipple) operation is a procedure performed in pancreas head cancers, duodenum, distal choledochal and ampulla tumors, chronic pancreatitis, and also major injuries of the pancreatic head containing the portal vein. ${ }^{1}$ It is a complex and high-risk surgical procedure. ${ }^{2}$ In recent years, the mortality rate has decreased markedly in the last two decades. ${ }^{3}$ Appropriate patient selection, increased surgical experience, developments in preoperative and postoperative follow-up, and multidisciplinary approach have contributed to better results. Nevertheless, even in experienced centres, mortality is still 1-5\% and total morbidity is 30-50\%., ${ }^{1,45}$

The most important complication after PPD is the development of pancreatic fistula which may lead to other major complications.

Correspondence to: Nazmi Özer, Adana City Research and
Training Hospital, Adana, Turkey

E-mail: nazmiozer83@gmail.com

Received: April 11, 2020; Revised: May 08, 2020;

Accepted: May 13, 2020

DOI: https://doi.org/10.29271/jcpsp.2020.05.480
According to ISGPF (International Study Group on Postoperative Pancreatic Fistula), the incidence of POPF varies between $5 \%$ and $30 \% .{ }^{6,7}$

Different types of pancreatojejunostomy anastomosis are used in PPD surgery. The commonly used techniques are: pancreatojejunostomy, Wirsungo jejunostomy, and Peng's technique. Although these techniques have individual or double comparisons in terms of fistula, there are no studies comparing all 3 techniques in literature. ${ }^{8 \cdot 10}$

The aim of this study was to determine the association between the pancreatic fistula and three different anastomosis techniques in patients undergoing proximal pancreaticoduodenectomy.

\section{METHODOLOGY}

This descriptive study was carried out by retrospectively analysing the data of 144 patients who underwent proximal pancreaticoduodenectomy (PPD) between January 2011 and January 2018 with the approval of the ethical committee number 24.03.2018/63 in General Surgery Clinic of Izmir Katip Celebi University Hospital.

Patient's age, gender and serum direct bilirubin values were recorded in the preoperative period. 
It was examined for pancreatic fistula development status, pathology of the resected tissue, serum albumin value, early mortality and anastomosis technique, in the postoperative period. The data were obtained by examining the medical records including pre- and post-operative clinical notes, surgical reports, laboratory results and pathology reports. Patients who were operated with a technique other than the three studied anastomotic techniques were excluded.

POPF (postoperative pancreatic fistula) was defined as being that the amylase value in the drain fluid obtained on the third postoperative day or after is three times higher than the serum amylase value, as suggested by the ISGPF (international study group on postoperative pancreatic fistula).

Three reconstruction techniques were evaluated to ensure the continuity of pancreatic stump namely end-to-end invagination (telescopic) pancreatojejunostomy (PJ, Figure 1a); end-to-side ducto-mucosal (Wirsungo jejunostomy, WJ, Figure 1b); and Peng's technique, a variant of the telescopic technique (Figure 1c). Stent was used in telescopic PJ anastomosis group only and none of the patients was given octreotide in postoperative period. The patients were divided into two groups as those who developed and not developed pancreatic fistula after PD operation.

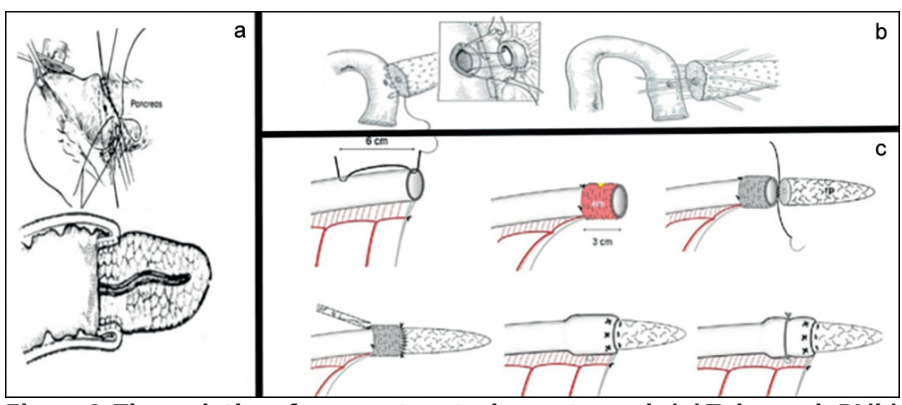

Figure 1: The varieties of pancreatoentericanastomosis (a) Telescopic PJ(b) Ductomucosal WJ (c) It schemes Peng's technique.

(em: everted mucosa, rp: residue of pancreas)

SPSS 22.0 programme was used for analysis of data. The normality of data distribution was evaluated with the Shapiro-Wilk test. One-Way ANOVA test was used together with bootstrap results in comparison of more than two independent groups by quantitative variables. In comparison of categorical data, Pearson, Chi-Square test was tested with Monte Carlo Simulation technique and Fisher's exact test. Quantitative data were expressed as mean \pm SD (standard deviation) and range (maximum-minimum) values in the tables. In addition, categorical data were expressed in $n$ (number) and percentages (\%). Values with $p$ $<0.05$ were considered significant.

\section{RESULTS}

The mean age of the patients was 62.94 (18-86). 38.2\% of the patients were aged 60 and under, and $61.8 \%$ of them were over the age of 60 . It was observed that POPF developed in $34 \%$ of patients aged 60 and under, and $17.6 \%$ of them over 60 years old. The differences between two groups were statistically significant $(p=0.029)$.

Majority i.e. $62.5 \%$ of the patients were males and $37.5 \%$ were females. POPF developed in $13.7 \%$ female patients and $29.9 \%$ male patients. The differences between two groups were statisti- cally significant $(p=0.032)$.

Table I: The relationship between risk factors and POPF status developing in patients underwent PPD.

\begin{tabular}{|c|c|c|c|}
\hline POPF & $\begin{array}{c}\text { Absent } \\
(\mathrm{n}=105) \\
\mathrm{n}(\%)\end{array}$ & $\begin{array}{c}\text { Present } \\
(n=33) \\
n(\%)\end{array}$ & $p$-value \\
\hline $\begin{array}{l}\text { Age } \\
\leq 60 \\
>60\end{array}$ & $\begin{array}{l}35(33.3) \\
70(66.7)\end{array}$ & $\begin{array}{l}18(54.5)^{b} \\
15(45.5)\end{array}$ & $\begin{array}{c}0.029 \\
2.40 \\
(1.08-5.32)^{\circ}\end{array}$ \\
\hline $\begin{array}{l}\text { Gender } \\
\text { Woman } \\
\text { Man }\end{array}$ & $\begin{array}{l}44(41.9) \\
61(58.1)\end{array}$ & $\begin{array}{c}7(21.2) \\
26(78.8)^{\mathrm{b}}\end{array}$ & $\begin{array}{c}0.032 \\
2.68 \\
(1.07-6.72)^{2} \\
\end{array}$ \\
\hline $\begin{array}{l}\text { Pathology } \\
\text { Adenocarcinoma } \\
\text { Intraepithelial neoplasia } \\
\text { Invasive ductal carcinoma } \\
\text { Chronic pancreatitis } \\
\text { Non-specific duodenitis } \\
\text { Neuroendocrine carcinoma } \\
\text { Pseudopapillary Tm. } \\
\text { Villous adenoma }\end{array}$ & $\begin{array}{c}86(81.9) \\
5(4.8) \\
0(0.0) \\
3(2.9) \\
1(1.0) \\
6(5.7) \\
3(2.9) \\
1(1.0)\end{array}$ & $\begin{array}{l}24(72.7) \\
3(9.1) \\
1(3.0) \\
2(6.1) \\
0(0.0) \\
1(3.0) \\
1(3.0) \\
1(3.0)\end{array}$ & 0.514 \\
\hline $\begin{array}{l}\text { Drain amylase } \\
\text { Normal } \\
\text { High }\end{array}$ & $\begin{array}{c}16(100.0) \\
0(0.0)\end{array}$ & $\begin{array}{c}0(0.0) \\
33(100.0)\end{array}$ & $<0.001$ \\
\hline $\begin{array}{l}\text { Serum direct bilirubin } \\
\text { (preoperatıve) } \\
<0.5 \\
\geq 0.5\end{array}$ & $\begin{array}{c}16(100.0) \\
0(0.0)\end{array}$ & $\begin{array}{l}13(39.4) \\
20(60.6)\end{array}$ & 0.655 \\
\hline $\begin{array}{l}\begin{array}{l}\text { Serum albumin } \\
\text { (postoperative) }\end{array} \\
\leq 3 \\
>3\end{array}$ & $\begin{array}{l}84(89.4) \\
10(10.6)\end{array}$ & $\begin{array}{c}27(96.4) \\
1(3.6)\end{array}$ & 0.454 \\
\hline $\begin{array}{l}\text { Ex in the early period } \\
\text { Absent } \\
\text { Present }\end{array}$ & $\begin{array}{c}103(98.1) \\
2(1.9)\end{array}$ & $\begin{array}{r}31(93.9) \\
2(6.1)\end{array}$ & 0.242 \\
\hline
\end{tabular}

Overall, $34.72 \%$ of the patients wereanastomosed with the telescopic PJ, $59.03 \%$ of them with the ducto-mucosal WJ, $6.25 \%$ of them with the Peng's technique. The POPF rate was determined as $19.1 \%(9 / 47)$ in the telescopic technique, $28 \%(23 / 82)$ in the ducto-mucosal technique, and $11.1 \%(1 / 9)$ in the Peng's technique. In 3 patients, each operated by telescopic technique and by ductomucosal technique, leakage status was evaluated as uncertain due to drain and patient problems. The pathological diagnoses of the resected specimen showed $80.6 \%$ adenocarcinoma, 5.6\% intraepithelial neoplasia, $4.9 \%$ neuroendocrine carcinoma, 3.5\% chronic pancreatitis, $2.8 \%$ pseudopapillary tumors, $1.4 \%$ villous adenoma, and $0.7 \%$ each of invasive ductal carcinoma and nonspecific duodenitis $(p=0.514)$.

Regarding postoperative serum albumin levels, it was $3.0 \mathrm{~g} / \mathrm{dL}$; and below in $90.98 \%$ (111/122), $24.3 \%$ of these patients developed POPF. The patients with postoperative serum albumin levels above of $3.0 \mathrm{~g} / \mathrm{dL}$ were $8.9 \%$ (11/122); and $9.1 \%$ of these patients developed POPF $(p=0.454)$. Preoperative serum direct bilirubin value of $0.5 \mathrm{mg} / \mathrm{dL}$ and above were found in $57.2 \%$ (79/138), $25.3 \%$ of these patients developed POPF. The same level was below $0.5 \mathrm{mg} / \mathrm{dL}$ in $42.7 \%$ (59/138), and $22.0 \%$ of these patients developed POPF $(p=0.655)$.

No statistically significant difference was found between the development pancreatic fistula, the highness of serum bilirubin 


\begin{tabular}{|c|c|c|c|c|c|}
\hline Anastomosis type & $\begin{array}{c}\text { Ductomucosal WJ. } \\
(\mathbf{n = 8 5 )} \\
\mathbf{n}(\%)\end{array}$ & $\begin{array}{l}\text { Peng's } \\
(n=9) \\
n(\%)\end{array}$ & $\begin{array}{l}\text { Telescopic PJ. } \\
(\mathbf{n = 5 0 )} \\
\mathbf{n}(\%)\end{array}$ & $\begin{array}{l}\text { Total } \\
(\mathrm{N}=144) \\
\mathrm{n}(\%)\end{array}$ & p-value \\
\hline $\begin{array}{l}\text { Age } \\
\text { Mean } \pm \text { SD. (max-min) }\end{array}$ & $62.17 \pm 11.23(86-18)$ & $61.89 \pm 10.74(76-42)$ & $64.46 \pm 11.37(83-33)$ & $62.94 \pm 11.23(86-18)$ & 0.500 \\
\hline $\begin{array}{l}\leq 60 \\
>60\end{array}$ & $\begin{array}{l}34(40.0) \\
51(60.0)\end{array}$ & $\begin{array}{l}3(33.3) \\
6(66.7)\end{array}$ & $\begin{array}{l}18(36.0) \\
32(64.0)\end{array}$ & $\begin{array}{l}55(38.2) \\
89(61.8)\end{array}$ & 0.856 \\
\hline $\begin{array}{l}\text { Sex } \\
\text { Woman } \\
\text { Man }\end{array}$ & $\begin{array}{l}31(36.5) \\
54(63.5)\end{array}$ & $\begin{array}{l}2(22.2) \\
7(77.8)\end{array}$ & $\begin{array}{l}21(42.0) \\
29(58.0)\end{array}$ & $\begin{array}{l}54(37.5) \\
90(62.5)\end{array}$ & 0.533 \\
\hline $\begin{array}{l}\text { Pathology } \\
\text { Adenocarcinoma } \\
\text { Intraepithelial neoplasia } \\
\text { Invasive ductal carcinoma } \\
\text { Chronic pancreatitis } \\
\text { Non-specific duodeniti } \\
\text { Neuroendocrine carcinoma } \\
\text { Pseudopapillary Tm. } \\
\text { Villous adenoma }\end{array}$ & $\begin{array}{l}74 \\
2 \\
1 \\
2 \\
0 \\
3 \\
3 \\
0\end{array}$ & $\begin{array}{l}5 \\
2 \\
0 \\
1 \\
0 \\
0 \\
1 \\
0\end{array}$ & $\begin{array}{l}37 \\
4 \\
0 \\
2 \\
1 \\
4 \\
0 \\
2\end{array}$ & $\begin{array}{c}116(80.6) \\
8(5.6) \\
1(0.7) \\
5(3.5) \\
1(0.7) \\
7(4.9) \\
4(2.8) \\
2(1.4)\end{array}$ & 0.142 \\
\hline $\begin{array}{l}\text { Fistula status } \\
\text { Absent } \\
\text { Present }\end{array}$ & $\begin{array}{l}59(72.0) \\
23(28.0)\end{array}$ & $\begin{array}{l}8(88.9) \\
1(11.1)\end{array}$ & $\begin{array}{l}38(80.8) \\
9(19.1)\end{array}$ & $\begin{array}{l}105(76.1) \\
33(23.9)\end{array}$ & 0.384 \\
\hline $\begin{array}{l}\text { Drain amylase } \\
\text { Normal } \\
\text { High }\end{array}$ & $\begin{array}{c}7(23.3) \\
23(76.7) \\
\end{array}$ & $\begin{array}{l}3(75.0) \\
1(25.0)\end{array}$ & $\begin{array}{l}6(40.0) \\
9(60.0) \\
\end{array}$ & $\begin{array}{l}16(32.7) \\
33(67.3)\end{array}$ & 0.077 \\
\hline $\begin{array}{l}\text { Serum direct bilirubin } \\
\text { (preoperatıve) } \\
<0.5 \\
\geq 0.5\end{array}$ & $\begin{array}{l}37(43.5) \\
48(56.5)\end{array}$ & $\begin{array}{l}5(55.6) \\
4(44.4)\end{array}$ & $\begin{array}{l}19(38.0) \\
31(62.0)\end{array}$ & $\begin{array}{l}61(42.4) \\
83(57.6)\end{array}$ & 0.631 \\
\hline $\begin{array}{l}\text { Serum albumin } \\
\text { (postoperative) } \\
\leq 3 \\
>3\end{array}$ & $\begin{array}{l}66(89.2) \\
8(10.8)\end{array}$ & $\begin{array}{c}7(100.0) \\
0(0.0)\end{array}$ & $\begin{array}{c}40(93.0) \\
3(7.0) \\
\end{array}$ & $\begin{array}{r}113(91.1) \\
11(8.9)\end{array}$ & 0.516 \\
\hline $\begin{array}{l}\text { Ex in the early period } \\
\text { Absent } \\
\text { Present }\end{array}$ & $\begin{array}{c}81(95.3) \\
4(4.7)\end{array}$ & $\begin{array}{l}8(88.9) \\
1(11.1)\end{array}$ & $\begin{array}{c}46(92.0) \\
4(8.0)\end{array}$ & $\begin{array}{c}135(93.7) \\
9(6.3)\end{array}$ & 0.535 \\
\hline
\end{tabular}

level in the preoperative period and the lowness of serum albumin level in the postoperative period. While the early mortality rate of patients undergoing PPD was $6.3 \%(9 / 144)$, when the groups developing POPF and those not developing were examined, no statistically significant difference was found between the presence of fistula and early mortality rates ( $p=0.242$, Tables I and II).

\section{DISCUSSION}

Many risk factors are described for pancreatic fistula development after PPD. ${ }^{11}$ Age, gender, degree of jaundice, malnutrition, pathology of periampullary region disease, resected pancreatic part, consistency of pancreatic stump, width of pancreatic duct, operation time, type of resection, technique of pancreatic anastomosis and intraoperative blood loss are included among these risk factors ${ }^{7,11}$ In this study, the rate of POPF in women over 60 years and female gender was statistically lower than male under 60 years of age.

Herrera et al. defined the risk factors for POPF. That factors are: over 70 years, male gender, and soft pancreatic tissue. ${ }^{12}$
In the study by Kow et al., PPD operation was performed in patients with over 65 years and under. When results were evaluated, the rate of POPF and complications were higher in patients over 65 years. ${ }^{13}$ While, the gender parameter in this study is parallel with the literature, the age parameter is not parallel with the literature. The likely reason for this result is additional disease and physical performance score, which may be better in elderly patients than the younger group.

In the present series, POPF was found in $22.9 \%(33 / 144)$; whereas mortality rate was $6.3 \%(9 / 144)$. The POPF rate was similar, and mortality rate was lower, when compared to the literature. In the series by Duffas et al., mortality was $11 \%$ and the rate of POPF was $18 \% ;{ }^{14}$ whereas Fang et al. determined that postoperative mortality was $8.9 \%$, postoperative morbidity was $56.4 \%$ and POPF was $17.6 \% .{ }^{15}$ The lower mortality rate after resection in the present series may be related not to the surgeon case load but to the level of experience in the various departments involved in the detection and management of postoperative complications, such as gastroenterology, radiology, or intensive care. 
While 9 (19.1\%) of 47 patients, who underwent telescopic PJ, developed POPF, 23 (28\%) of 82 patients developed POPF who underwent ductomucosal WJ. In the Peng's technique, this rate was found to be $11.1 \%(1 / 9)$. Although the comparison of these three methods is not statistically significant $(p=0.384)$, the low rate of fistula in Peng's technique was remarkable compared to other techniques.

Yang et al. decided to choose the anastomosis technique according to the state of the residual pancreatic tissue. They concluded that ductomucosal WJ should be performed without a stent in patients whose pancreatic duct diameter is dilated $(>3 \mathrm{~mm})$. Telescopic type PJ should be performed with stent in patients whose pancreatic residual tissue is soft and pancreatic duct diameter is not dilated, again, no statistically significant difference was found when anastomosis types, telescopic $\mathrm{PJ}$ and ducto mucosal WJ were compared in terms of POPF. ${ }^{16}$

In the study by Yingbin et al., POPF rates were found in 100 patients, upon whom they performed the Peng's technique. ${ }^{17}$ In the study by Javier et al., 2 (6.7\%) POPF was determined in 30 patients who underwent Peng's technique. ${ }^{18}$ In the light of the available literature and the results of this study, leakage rates are lower in Peng's technique compared to other techniques.

Two general factors-serum direct bilirubin level in the preoperative period and serum albumin level in the postoperative period-were not statistically significant, when compared between groups with and without pancreatic fistula. These results are in line with the literature. ${ }^{16,19}$ In their first series, Yeo and Cameron regarded these two factors among risk factors in pancreatic fistula development. ${ }^{1}$ Whereas, in their later study, they reported them as a general risk factor, not specific to pancreatic fistula. ${ }^{19}$

In the prevention of pancreatic fistula, methods such as placing a stent in the pancreatic duct and the use of octreotide in the postoperative period have also been tried; accordingly, it was not observed that the stenting had effects such as protection from fistula and reduction in rate of leak, and also it was observed that it caused different complications such as pancreatic duct obstruction. ${ }^{20,21}$ In addition, the use of octreotide was not observed to be a prohibitive on fistula development with reducing pancreatic exocrine secretion. ${ }^{19,22-25}$

Considering the pathology results, adenocarcinoma was observed in $80.6 \%$. Additionally, pancreatitis and other tumoral formations were observed at a lower frequency. When the fistula rates were compared in relation with the pathology results, there was no statistically significant difference.

\section{CONCLUSION}

In this study, no statistically significant difference was found between the three techniques in terms of POPF rates. Leakage rate was lower in Peng's technique compared to other techniques.No effect of parameters except age and gender was found statistically significant on POPF rates being lower in female gender and over age 60 patients. Ducto mucosal WJ should be performed in patients with hard pancreatic tissue and dilated duct. Peng's technique should be performed in patients with soft pancreatic tissue and non-dilated/narrowed duct.

\section{ETHICAL APPROVAL:}

The ethics committee approval of our study was obtained before the study started and it was accepted with the approval of the ethics committee at the General Surgery Clinic of Izmir Katip Celebi University Atatürk Training and Research Hospital.

\section{PATIENTS' CONSENT:}

Consent for the participation in study was not obtained from patients as data was collected from medical record without disclosing the indentity of participants.

\section{CONFLICT OF INTEREST:}

Authors declared no conflict of interest.

\section{AUTHORS' CONTRIBUTION:}

NO: Concept, supervision, interpretation and critical review. OYY: Design, data collection, processing and writing manuscript.

\section{REFERENCES}

1. Yeo CJ, Cameron JL, Sohn TA, Lillemoe KD, Pitt HA, Talamin $\mathrm{MA}$, et al. Six hundred and fifty consecutive pancreaticoduodenectomies in the 1990s: Pathology, complications, and outcomes. Ann Surg 1997; 226(3):248-57.

2. Kayahara M, Nagakawa T, Ueno K, Ohta T, Takeda T, Miyazaki I. An evaluation of radical resection for pancreatic cancer based on the mode of recurrence as determined by autopsy and diagnostic imaging. Cancer 1993; 172(7):2118-23.

3. Gouma DJ, van Geenen RC, van Gulik TM, de Haan RJ, de Wit $\mathrm{LT}$, Busch OR, et al. Rates of complications and death after pancreaticoduodenectomy: Risk factors and the impact of hospital volume. Ann Surg 2000; 232(6):786-95.

4. Yeo CJ. The Johns Hopkins experience with pancreaticoduodenectomy with or without extended retroperitoneal lympadenectomy for periampullary adenocarcinoma. J Gastrointest Surg 2000; 4(3):231-2.

5. Pedrazzoli S. Pancreatoduodenectomy (PD) and postoperative pancreatic fistula (POPF): A systematic review and analysis of the POPF-related mortality rate in 60,739 patients retrieved from the English literature published between 1990 and 2015. Medicine (Baltimore) 2017; 96(19):e6858.

6. Ho IG, Kim JK, Hwang HK, Kim JY, Park JS, Yoon DS. Does international study group on pancreatic fistula (ISGPF) classification need modification after distal pancreatectomy? Korean J Hepatobiliary Pancreat Surg 2014; 18(3):90-3.

7. Distler M, Kersting S, Rückert F, Kross P, Saeger H.D, Weitz J, et al. Chronic pancreatitis of the pancreatic remnant is an independent risk factor for pancreatic fistula after distal pancreatectomy. BMC surgery 2014; 14:54.

8. Kawaida $\mathrm{H}$, Kono $\mathrm{H}$, Hosomura $\mathrm{N}$, Amemiya $\mathrm{H}$, Itakura J, Fujii $\mathrm{H}$, et al. Surgical techniques and postoperative management to prevent postoperative pancreatic fistula after pancreatic surgery. World J Gastroenterol 2019; 25(28):3722-37.

9. Wang W, Zhang Z, Gu C, Liu Q, Liang Z, He W, et al. The optimal choice for pancreatic anastomosis after pancreaticoduodenectomy: A network meta-analysis of 
randomized control trials. Int J Surg 2018; 57:111-6.

10. Gupta S, Attri AK, Sharma R, Gureh M, Nasir MI. Binding pancreaticojejunostomy: Is It Safe? Niger J Sur 2020; 26(1): 48-52.

11. Crıppa S, Salvıa R, Falconı M, Butturını G, Landonı L, Bassı C. Anastomotic leakage in pancreatic surgery. HPB (Oxford) 2007; 9(1):8-15.

12. Herrera J, Zazpe C, Sánchez P, Tarifa A, Eguaras I, Lera JM. Feasibility and morbidity and mortality in two hundred consecutive cases of pancreaticogastrostomy after pancreaticoduodenectomy. Cir Esp 2019; 97(9):501-9.

13. Kow AWC, Sadayan NA, Ernest A, Wang B, Chan C.Y, Ho CK, et al. Is pancreaticoduodenectomy justified in elderly patients? Surgeon 2012; 10(3):128-36.

14. Hu BY, Wan T, Zhang WZ, Dong JH. Risk factors for postoperative pancreatic fistula: Analysis of 539 successive cases of pancreaticoduodenectomy. World J Gastroenterol 2016; 22(34):7797-805.

15. Duffas JP, Suc B, Msika S, Fourtanie G, Muscari F, Hay JM, et al. Associations for research in surgery. A controlled randomized multicenter trial of pancreatogastrostomy or pancreatojejunostomy after pancreatoduodenectomy. Am J Surg 2005; 189(6);720-9.

16. Yang $Y M$, Tian XD, Zhuang $Y$, Wang WM, Wan YL, Huang YT. Risk factors of pancreatic leakage after pancreaticoduodenectomy. World J Gastroenterol 2005; 11(16): 2456-61.

17. Liu Y, Wang J, Xu B, Li H, Zhe T, Fang H, et al. Peng's pancreaticojejunal anastomosis (binding pancreaticojejunostomy) for the pancreato-duodenectomy- A new procedure ensuring no leakage. Chinese-German J Clin Oncol 2002; 1:65-7.

18. Targarona J, Barreda L, Pando E, Barreda C. Is peng's pancreaticojejunal anastomosis more effective than mucosamucosa anastomosis in duodenopancreatectomy for pancreatic and peri-ampullary tumours? Cirugía Española (English Edition) 2013; 91(3):163-8.

19. Yeo CJ, Cameron JL, Lillemoe KD, Sauter PK, Coleman J, Sohn $\mathrm{TA}$, et al. Does prophylactic octreotide decrease the rates of pancreatic fistula and other complications after pancreaticoduodenectomy? Results of a prospective randomized placebo-controlled trial. Ann Surg 2000; 232(3):419-29.

20. Casadei R, Ricci C, Silvestri S, Campra D, Ercolani G, D'Ambra $M$, et al. Peng's binding pancreaticojejunostomy after pancreaticoduodenectomy. An Italian, prospective, dualinstitution study. Pancreatology 2013; 13(3):305-9.

21. Suzuki Y, Fujino Y, Tanioka Y, Hiraoka K, Takada M, Ajiki T, et al. Selection of pancreaticojejunostomy techniques according to pancreatic texture and duct size. Arch Surg 2002; 137(9): 1044-7.

22. Poon RT, Lo SH, Fong D, Fan ST, Wong J. Prevention of pancreatic anastomotic leakage after pancreaticoduodenectomy. Am J Surg 2002; 183(1):42-52.

23. Peng YP, Zhu XL, Yin LD, Zhu Y, Wei JS, Wu JL, et al. Risk factors of postoperative pancreatic fistula in patients after distal pancreatectomy: A systematic review and metaanalysis. Sci Rep 2017; 7(1):185.

24. Yang X, Patel S, Cunningham SC. The harm of prophylactic octreotide in pancreatoduodenectomy: More artefact than fact? HPB (Oxford) 2015; 17(4):371.

25. Jin K, Zhou H, Zhang J, Wang W, Sun Y, Ruan C, et al. Systematic review and meta-analysis of somatostatin analogues in the prevention of postoperative complication after pancreaticoduodenectomy. Dig Surg 2015; 32(3): 196-207. 